\title{
Rehabilitation of mandibular partial edentulous patient with remain- ing unilateral teeth using implant-assisted removable partial denture
}

\author{
Hyo-Gyoung Yi, Kwang-Yeob Song, Seung-Geun Ahn, Ju-Mi Park, and Jae-Min Seo* \\ Department of Prosthodontics, School of Dentistry and Institute of Oral Bio-Science, Chonbuk National University, \\ Jeonju 54896, Republic of Korea
}

(Received May 8, 2018; Revised version received Jun 4, 2018; Accepted Jun 5, 2018)

\begin{abstract}
For patients with a few remaining teeth, if an implant supported fixed partial denture is difficult due to the patient's systemic or local conditions, or due to their economic situation, a removable partial denture may be considered as a treatment option. If a few teeth remain unilaterally to the midline, placement of the implant on the contralateral side and designing an implant-assisted removable partial denture (IARPD) may improve the retention and support of the removable partial denture and protect weak abutment teeth. In this case, a partially edentulous patient with a few remaining teeth located unilaterally on the mandible was treated using a maxillary distal extension removable partial denture and mandibular IARPD after implant placement on the mandibular edentulous area. We achieved an esthetically and functionally satisfying outcome.
\end{abstract}

KEY WORDS: Distal extension removable partial denture, Implant, Implant-assisted removable partial denture, Partial edentulism

\section{서 론}

부분 무치악 환자는 고정성 보철, 가철성 국소의치, 임 플란트 지지 고정성 보철로 수복될 수 있으며, 소수의 잔 존 치아가 있는 경우에는 고정성 보철로 치료하는 것이 불 가능하여 가철성 국소의치나 임플란트 지지 고정성 보철 수복 치료를 시행하게 된다. 그러나 환자의 전신적, 국소 적 그리고 경제적 여건에 따라 임플란트 지지 고정성 보 철 수복이 어려운 경우 가철성 국소의치를 고려해볼 수 있 다[1]. 그러나 후방 연장 국소의치는 장기간 사용 시 수직 고경을 상실하거나 교합평면의 부조화가 발생할 수 있고 외팔보 효과에 의해 잔존치에 응력이 집중되어 환자의 불 편감을 유발할 수 있으며 저작 기능의 회복이 불안정하다. 이를 극복하기 위해 무치악 부위에 임플란트를 식립해 부 가적인 유지와 지지를 얻는 임플란트 보조 국소의치 (implant-assisted removable partial denture, IARPD)에 대 한 관심이 높아지고 있다[2,3].

\section{*Corresponding author: Jae-Min Seo}

Department of Prosthodontics, School of Dentistry and Institute of Oral Bio-Science, Chonbuk National University, 567 Baekje-daero, Deokjingu, Jeonju 54896, Republic of Korea

Tel.: +82-63-250-2696, Fax: +82-63-250-2218

E-mail: jmseo@jbnu.ac.kr
국소의치는 지대치에 의한 대칭적인 지지가 중요하며, 중심선에 대해 편측으로 소수의 치아만 남은 경우 지점선 에 대해 지대치에 유해한 스트레스를 가하게 된다. 이런 경우 전략적 위치에 최소한의 임플란트를 식립하는 것이 추천된다[4]. 국소의치를 위한 임플란트는 지지에 가장 유 리한 위치에 식립되어야 국소의치의 회전운동이 효과적으 로 억제된다. 의치상에서 지지 받지 못하는 부위에 임플란 트를 적용하면 이러한 회전운동을 없애거나 지렛대의 길 이를 감소시켜 지렛대 효과를 줄일 수 있다[5].

본 증례는 하악 우측에 편측으로 지대치가 존재하는 상 하악 양측성 후방 연장 부분 무치악 환자에서 하악 좌측 측절치와 견치 사이, 제 1 소구치와 제 2 소구치 사이에 임 플란트를 식립하고 상악은 전통적 국소의치를, 하악은 Locator $^{\circledR}$ 유지장치를 부착한 임플란트 보조 국소의치를 제 작하여 심미적, 기능적으로 만족할만한 임상 결과를 얻었 기에 보고하고자 한다.

\section{증례보고}

본 환자는 79세 여성으로 상하악 의치로 인한 불편감과 무치악 부위의 통증을 주소로 본과에 내원하셨으며, 수년 전에 제작한 상하악 써베이드 보철물 및 국소의치를 사용 


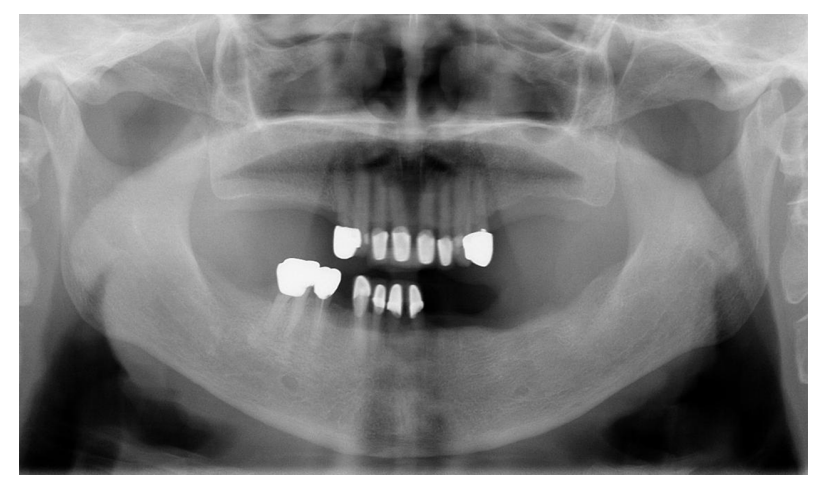

Fig. 1. Pre-treatment panoramic radiograph.

하고 있었다. 초진 시 구내 사진 및 파노라마 방사선 사진 상에서 상하악 구치부 무치악 부위에 중등도의 치조골 흡 수와 다수의 구치부 치아 상실이 관찰되었고, 임상 검사에 서 \#43의 도재 파절, \#31, 41의 1 2도의 치아 동요도, \#43, 45,46 의 타진 및 저작 시 통증을 보였고 \#11, 21, 22, 31 의 보철물 하방에 2 차 우식이 의심되어 보철물 제거 후 지 대치 평가가 필요하였다(Fig. 1 and 2).

진단 과정에서 관찰된 내용을 근거로 무치악 부위가 넓 은 하악 좌측에 임플란트를 식립하고 기능성과 심미성을 회복하기 위해 전악 수복하기로 결정하였다. 환자는 고령 으로 인해 광범위한 수술을 원하지 않았고 경제적인 치료 를 원하였다. 잔존 치아의 우식 및 치주 치료 후 보철 치 료를 계획하였으며, 첫 번째 방안으로 가용골이 풍부한 \#44 위치 및 \#32에서 \#35 부위에 임플란트 식립 후 잔존
치아와 임플란트를 포함한 고정성 수복을 하고 무치악 부 위에 통상적인 후방연장 국소의치를 제작하거나, 두 번째 방안으로 임플란트 식립 후 잔존 치아에만 고정성 수복을 시행하고 상악은 국소의치를, 하악은 임플란트 보조 국소 의치를 고려하였다. 하악 임플란트 보조 국소의치의 유지 장치는 Locator ${ }^{\circledR}$ (Zest Anchors Inc., Escondido, CA, USA) 로 선택하였다.

초진 시 예비 인상 채득하고 안궁이전 및 악간 관계 채 득하여 반조절성 교합기(Hanau modular articulator system 190, Whip Mix Co., Luisville, KY, USA)에 진단 모형을 장착하였다. 교합면 간 거리, 전정 간 거리, 안모 계측, 심 미, 발음 등을 참고하여 수직고경 평가한 결과 수직고경 상실을 보이지 않아 기존의 수직고경을 유지하기로 하였 다. 이상적인 교합평면을 가지도록 전악 납형 형성을 시행 하였고 우측방 운동 시에는 견치 유도 교합, 좌측방 운동 시에는 의치의 안정과 임플란트에 가해지는 응력의 분산 을 위해 견치부터 소구치까지 군기능 교합을 부여하고 전 방 운동 시에는 상악 좌우측 중절치에 의해 유도되도록 하 였다(Fig. 3).

이후 납형 형성을 토대로 임시보철물을 제작하여, 환자 에게 장착하였다. 상하악 잔존치의 기존의 보철물을 제거 한 결과 2 차 우식이 심하게 진행되어 $\# 14,24,31,46$ 의 발 거가 필요하였다. \#31, 46 발치 시 하악은 우측 중절치부 터 우측 제 2소구치까지 편측으로 소수의 치아가 잔존하 게 되며, 치주적으로 약한 하악 우측 중절치는 직접적으로 의치의 유지를 부담하기에는 부적절하여 대합치 및 반대

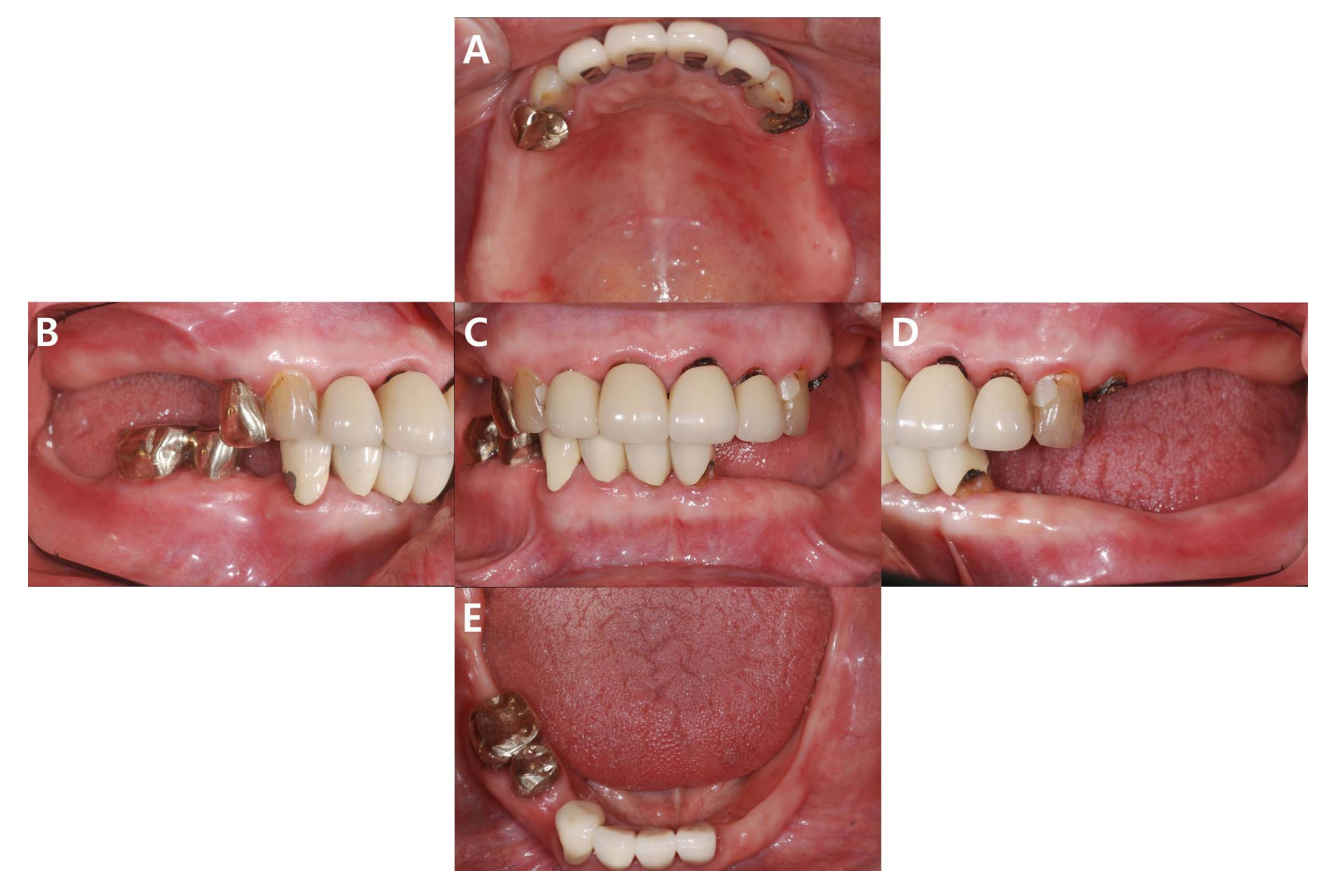

Fig. 2. Intra-oral status in the initial examination. (A) Maxillary occlusal view, (B) right lateral view, (C) frontal view at maximum inter-cuspal position, (D) left lateral view, and (E) mandibular occlusal view. 


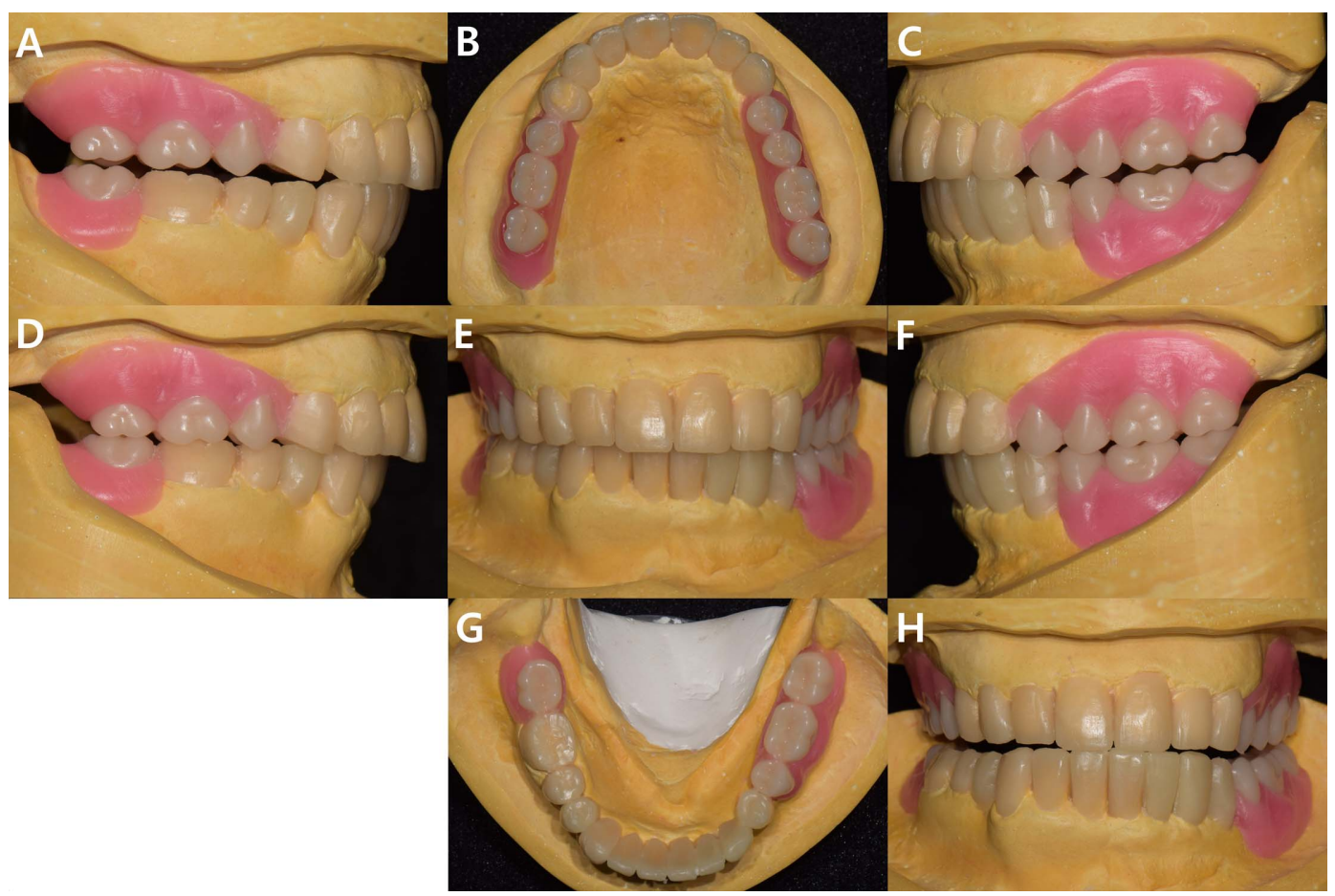

Fig. 3. Diagnostic wax up model. (A) Lateral movement-right side: canine guidance, (B) maxillary occlusal view, (C) lateral movement-left side: group function, (D) right lateral view, (E) frontal view, (F) left lateral view, (G) mandibular occlusal view, and (H) anterior movementanterior side: group function.

측 치아와 대칭적 위치이면서 가용골이 풍부한 하악 좌측 측절치부터 소구치 부위에 임플란트 식립을 계획하였다. 스텐트를 이용하여 컴퓨터 단층 사진을 촬영하였으며, 환 자가 \#44 부위에는 임플란트 치료를 원하지 않아 해당 상 실치 부위는 통상적인 고정성 보철 수복으로 치료 계획을 변경하였다. 무치악부위 가용골에 적합한 길이와 직경의 임플란트를 선택하였으며 고령인 점을 감안하여 임플란트 식립 시 추가적인 골유도재생술은 시행하지 않기로 하였 다. 따라서 골유도재생술을 시행하지 않고도 임플란트 고 정성 보철 수복보다 더 자유롭게 가용골이 풍부한 위치에 임 플란트를 식립할 수 있으며, 외팔보 효과의 감소에 의해 임 플란트에 가해지는 응력이 감소될 수 있도록 보철적 치료 계 획의 두 가지 방안 중에서 두 번째 방안을 선택하였다.

본원 보철과에서 \#32와 \#33 사이, \#34와 \#35 사이에 해 당하는 위치에 임플란트(\#32와 \#33 사이 : $3.5 \times 11.5 \mathrm{~mm}, \# 34$ 와 \#35 사이 : $4.5 \times 10 \mathrm{~mm}$ (TS III SA, Osstem, Seoul, Korea)) 를 식립하고 \#14, 24, 31, 46을 발거했다(Fig. 4). 임플란트 식립 및 발치 1 주 뒤 임시의치를 장착하였다. 본원 보존과 에서 \#21, 23, 43, 45의 근관 치료와 \#11, 13의 우식 치료 를 하였으며, 치주과에서 잔존 지대치의 치주 치료를 시행 하였다.

환자는 2 개월 간 임시보철물 사용 후 심미적, 기능적으 로 만족해하여, 최종보철물을 제작하기로 하였다. 부가중

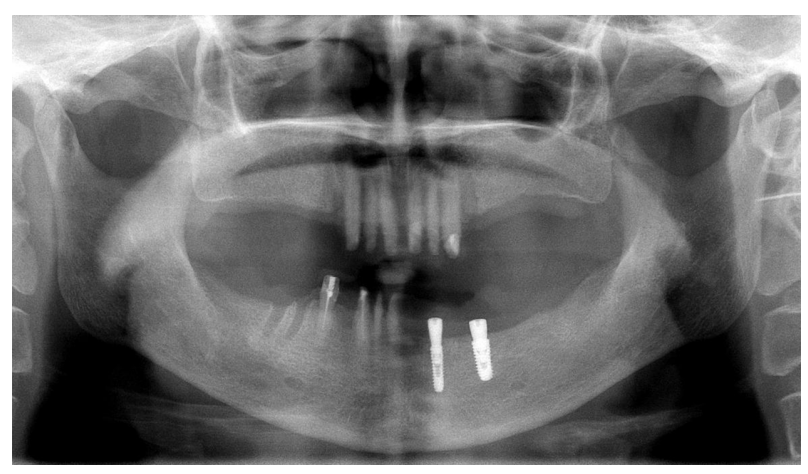

Fig. 4. Panoramic radiograph after implants placement on mandibular left edentulous area.

합형 실리콘 인상재(Aquasil Ultra XLV, Monophase, Dentsply Caulk, Milford, USA)를 이용하여 상하악 국소의 치 지대치의 최종 인상을 채득하고 작업 모형을 제작하였 다(Fig. 5). 악간관계를 채득하고 작업모형을 교합기에 장 착 후, 최종 보철물을 제작하였다. 임시치아 상태의 모형 을 참고로 왁스업하여 스캔하였다. \#13, 12, 11, 21, 22, 23, 41, 42는 지르코니아 코어(Upcera Zirconia Block, Liaoning Upcera Co., Guangdong, China)에 상부도재(IPS e.max Ceram, Ivoclar Vivadent, Schaan, Germany)를 축성한 지르코니아도재 전장 보철물로, $\# 43=45$ 는 단일구조 지르코니아 보철 
Hyo-Gyoung Yi et al.

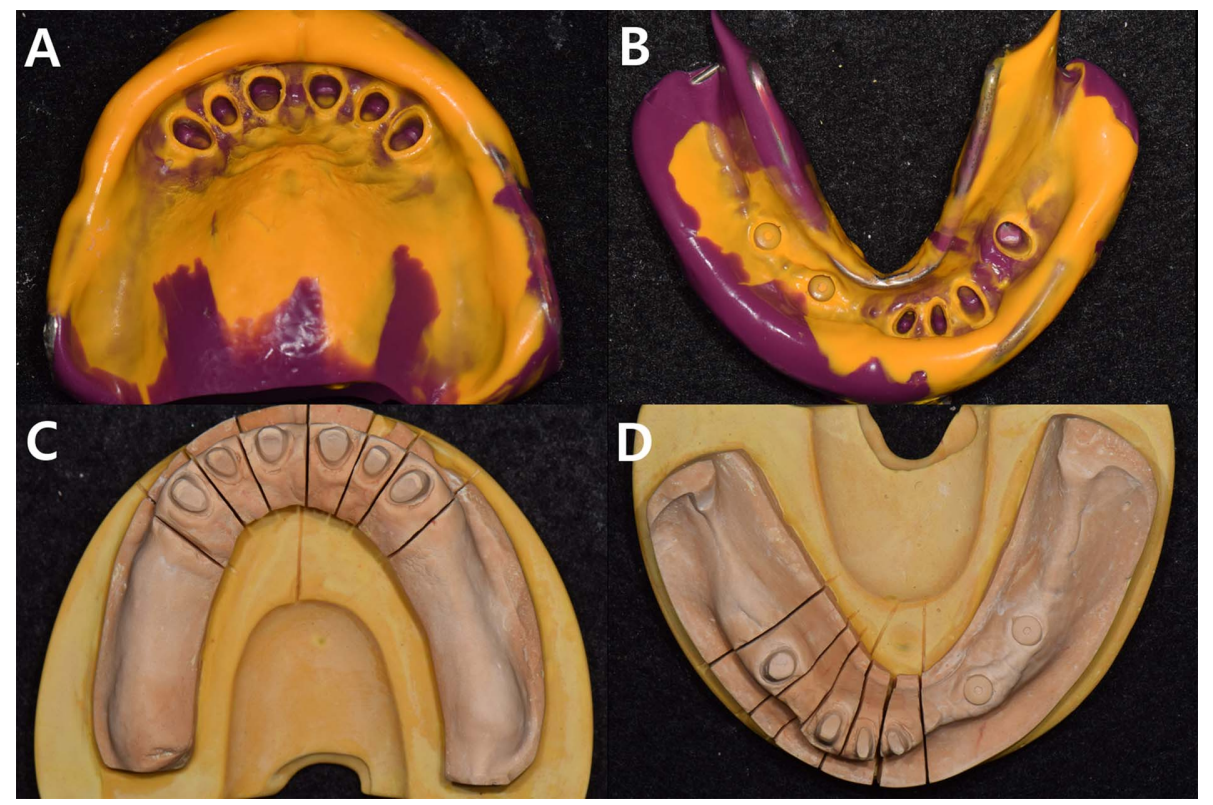

Fig. 5. Mater cast fabrication for fixed prostheses. (A) Maxillary final impression, (B) mandibular final impression, (C) maxillary master cast, and (D) mandibular master cast.

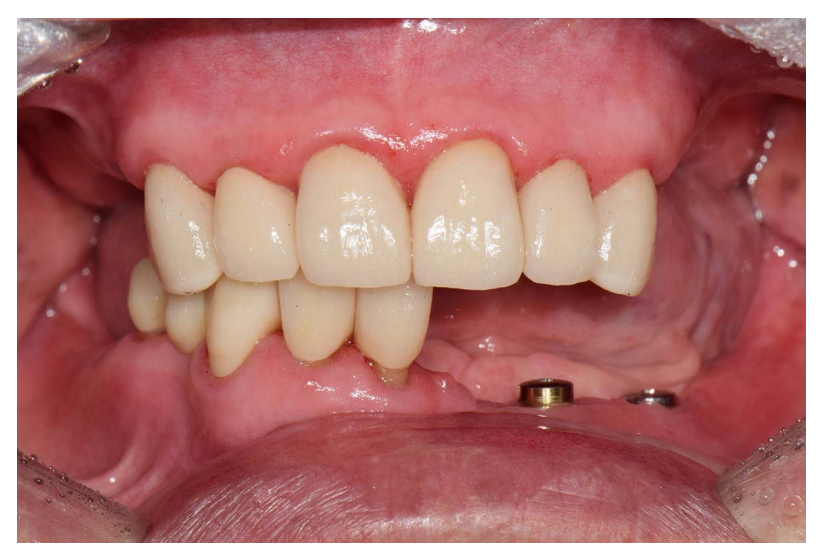

Fig. 6. Definitive fixed prostheses.

물로 제작하고 레진시멘트(RelyX Ultimate ${ }^{\circledR}, 3 \mathrm{M}$ ESPE, St. Paul, MN, USA)로 최종 합착하였다(Fig. 6).
상악의 양측성 후방 연장 국소의치와 하악의 임플란트 보조 국소의치 제작을 위하여 하악 좌측 임플란트에 Locator $^{\circledR}$ 지대주를 체결 후 알지네이트 인상재(Aromafine Plus, GC, Tokyo, Japan)로 예비 인상 채득하였다. 개인트 레이를 제작하여 모델링 컴파운드(Peri compound, GC, Tokyo, Japan)를 이용하여 변연 형성 후 부가중합형 실리 콘 인상재(Aquasil Ultra XLV, LV, Dentsply Caulk, Milford, USA)를 이용하여 최종 인상 채득 하였다. 이후 통법대로 국소의치를 제작하고 최종 의치를 교합 조정 후 구강 내 에 장착하였다. 의치의 침하 보상을 위해 장착 2 주 후 Locator $^{\circledR}$ 유지장치의 male part를 자가 중합 아크릴릭 레 진(Pattern Resin LS, GC America Inc., Alsip, IL, USA)을 이용해 직접법으로 부착하고 전치부 심미성을 개선하고 치주적으로 약한 \#41에 가해지는 측방력을 최소화하기 위 해 \#41의 가공선을 제거하였다(Fig. 7). 의치 장착 후 전방

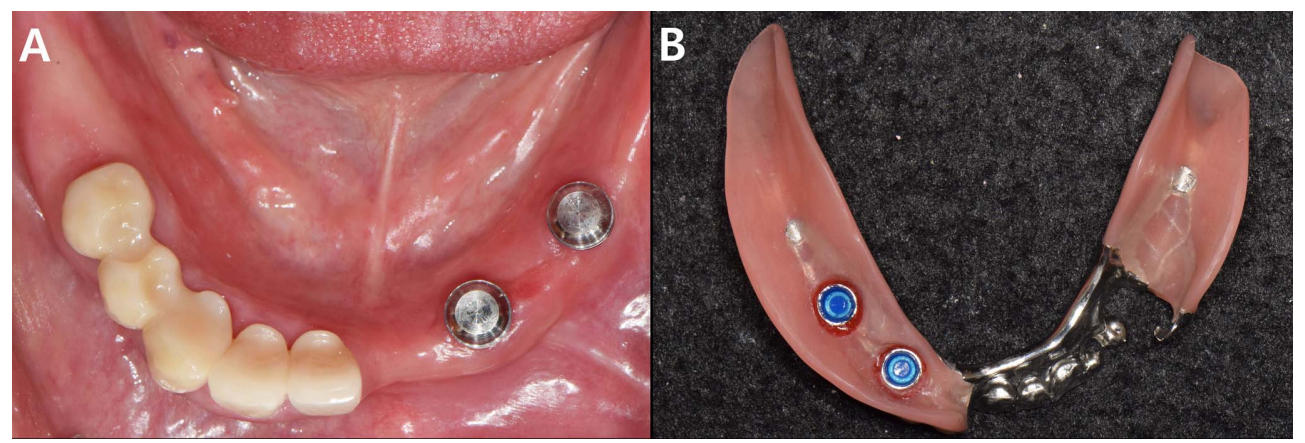

Fig. 7. Locator ${ }^{\circledR}$ attachments connection. (A) Locator ${ }^{\circledR}$ abutments \& processing caps were connected to the implants. (B) Ventral view of mandibular IARPD. Metal housing and blue nylon patrix were inserted. 


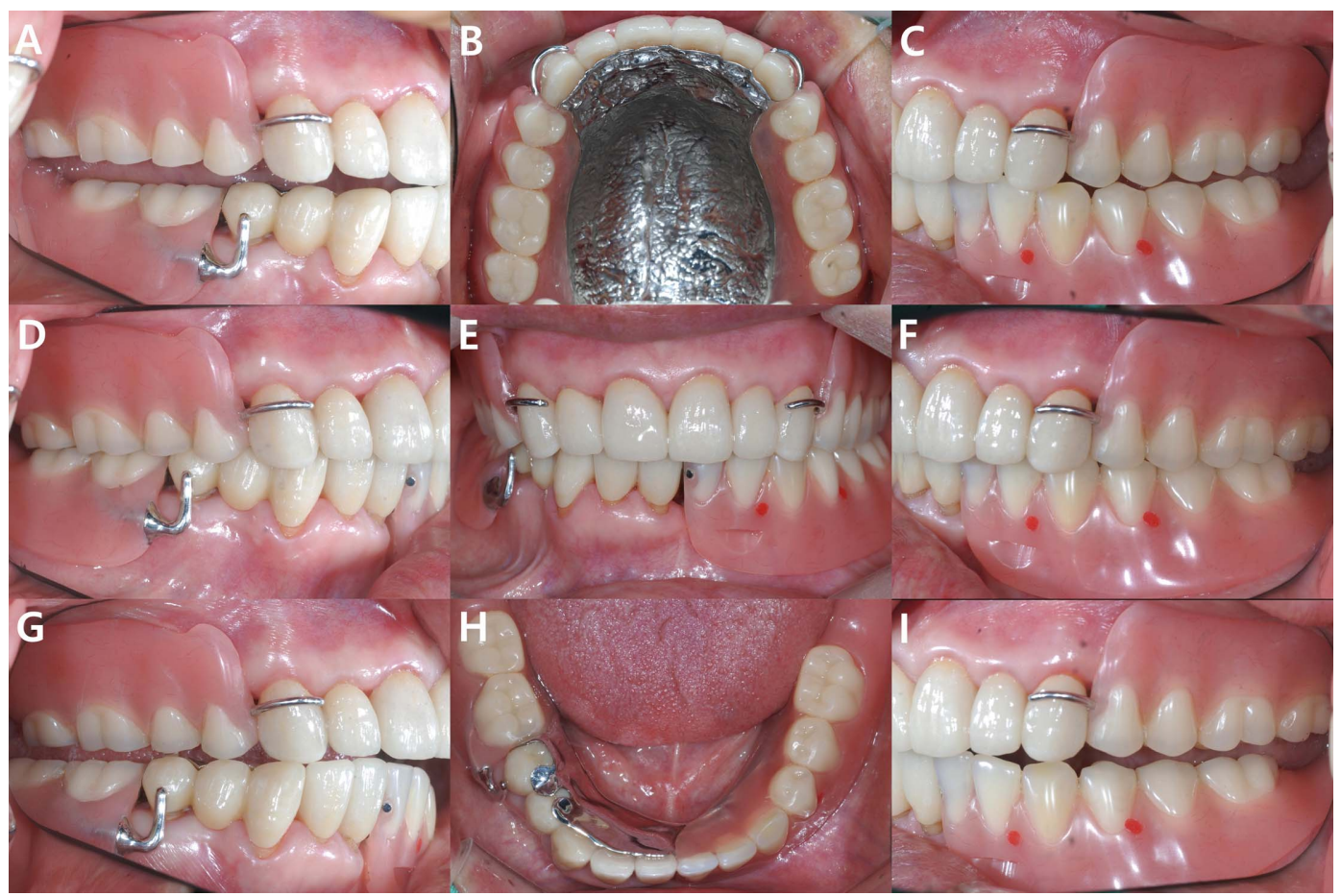

Fig. 8. Mandibular IARPD. (A) Balancing side during left lateral excursion, (B) maxillary occlusal view, (C) working side during left lateral excursion, (D) right lateral view, (E) frontal view at maximum inter-cuspal position, (F) left lateral view, (G) working side during right lateral excursion, $(\mathrm{H})$ mandibular occlusal view, and (I) balancing side during right lateral excursion.

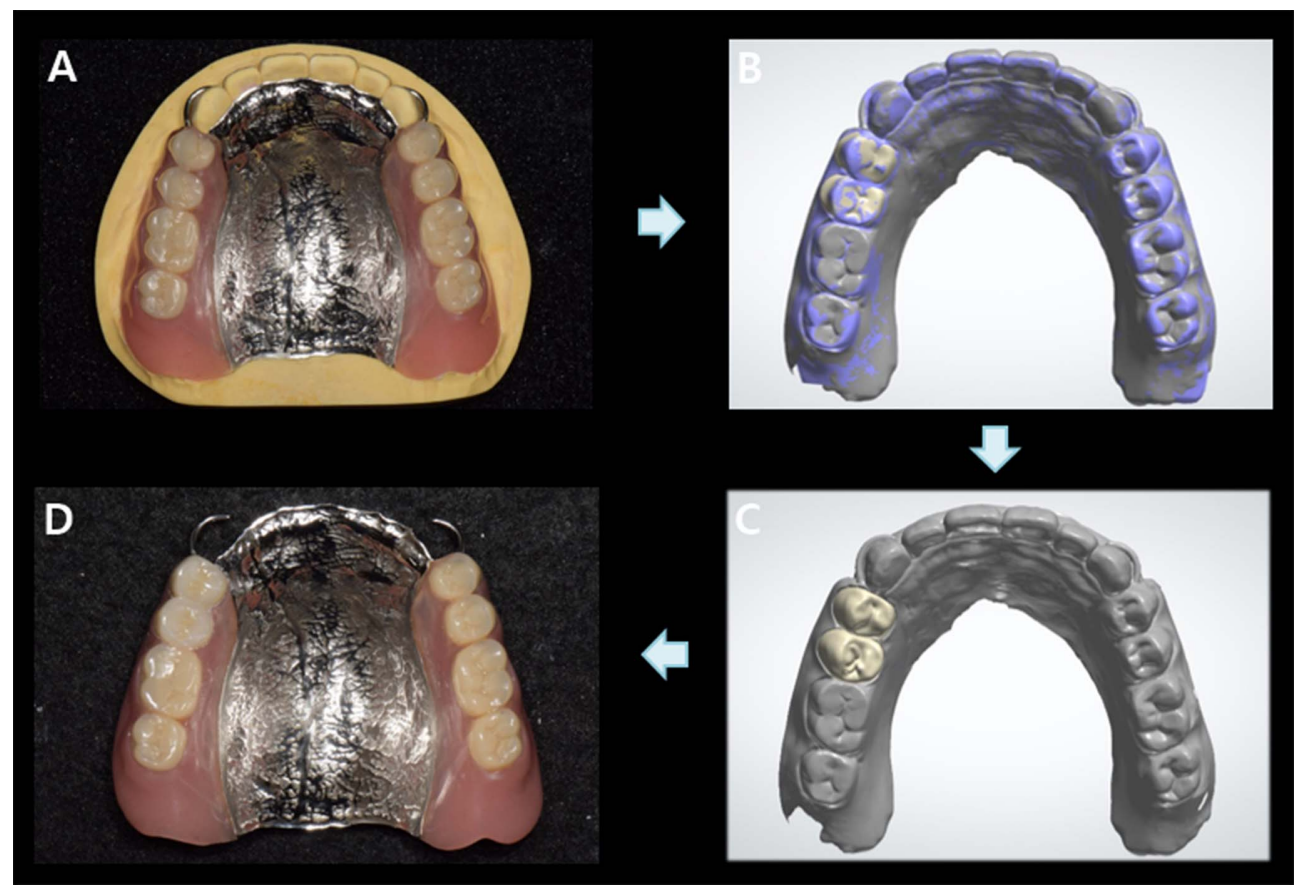

Fig. 9. Replacement of resin occlusal plane with zirconia occlusal plane. (A) Working cast fabrication by pick-up impression of maxillary RPD. (B and C) CAD design of zirconia occlusal plane by double scanning method. (D) Final maxillary RPD after cementation of zirconia occlusal prostheses on the occlusal surface.

운동 시 구치부 이개 및 우측방 운동 시 견치유도 교합, 좌측방 운동 시 군기능 교합을 이루고 있음을 재확인하였
다(Fig. 8). 환자에게 잔존 자연치아와 Locator ${ }^{\circledR}$ 지대주를 포함한 구강위생 및 의치 관리에 대한 교육을 시행하였다. 


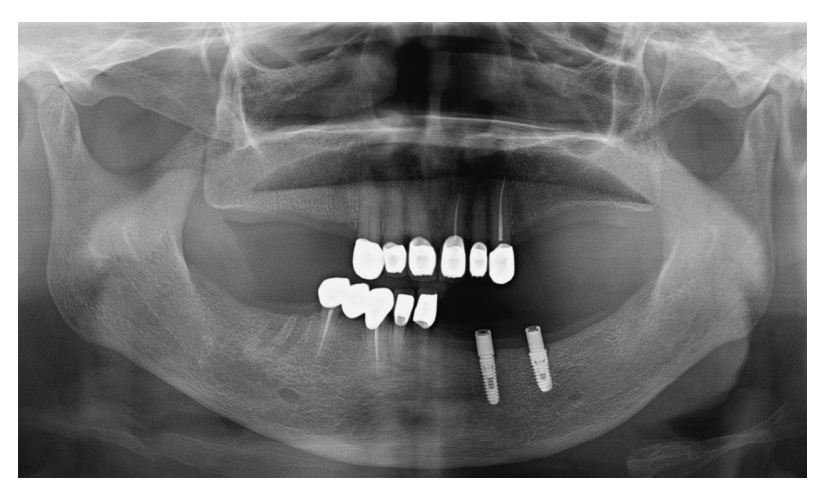

Fig. 10. Post-treatment panoramic radiograph.

최종 의치 장착 5 개월 후 의치에 대한 환자의 적응과 안 정적인 교합을 확인한 뒤에 하악의 지르코니아 보철물과 대합되는 상악 의치의 레진 인공치의 마모에 의한 가철성 국소의치의 지지의 감소 및 대합치의 정출로 인한 교합평 면의 부조화를 방지하기 위해 \#14, 15 인공치의 교합면을 지르코니아로 교체하기로 하였다. 상악 국소의치를 pick up 인상 채득하고 기존의 인공치 교합면을 삭제한 후(기능 교두: $2 \mathrm{~mm}$, 비기능 교두: $1.5 \mathrm{~mm}$, 치경부에서 변연 두께: $1 \mathrm{~mm}$ ) double scanning 방법으로 제작한 지르코니아 보철 물을 삭제된 인공치 위에 레진 시멘트(RelyX Unicem ${ }^{\circledR}$, $3 \mathrm{M}$ ESPE, St. Paul, MN, USA)를 이용하여 합착하였다 (Fig. 9). 환자는 기능적, 심미적으로 만족하였으며, 의치 장착 후 1 일, 1 주, 2 주, 1 개월, 5 개월, 6 개월, 7 개월, 1 년의 정기적인 재내원을 통해 구강위생 관리의 정도, 교합상태 의 변화 유무 등을 검사하였다(Fig. 10).

\section{고 찰}

임플란트 보조 국소의치에서 임플란트의 성공률은 $93 \sim 100 \%$ 로 다양하며, 전통적 국소의치에 비해 높은 환자 만족도를 보인다[2]. Wismeijer 등[6]은 기존 의치에 비해 임플란트 유지 국소의치에서 환자 만족도, 저작 효율, 의 치 안정성, 발음에 대한 만족도가 유의하게 증가하였다고 보고하였다. Ohkubo 등[3]도 전통적인 국소의치와 치유지 대주를 연결한 임플란트 지지 국소의치를 비교한 결과 임 플란트 지지 국소의치에서 저작 시간이 짧고 교합 접촉 중 심이 후방으로 위치하였으며 유의하게 높은 교합력과 환 자 만족도를 보였다고 하였다.

국소의치를 위한 임플란트 식립 위치 선정 시 고려사항 으로는 의치의 지지, 안정, 유지와 잔존치조제의 해부학적 형태, 전략적인 지대치의 상실 여부, 대합치의 상태, 최후 방 지대치의 상태가 있다[5]. 임플란트 식립 위치에 관한 다양한 의견이 제시되었는데, Grossmann 등[7]은 가장 강
한 힘이 가해지는 최후방부를 추천하였으나, 후방 치조제 가 부족하거나 지대치의 예후가 불량한 경우 및 클라스프 를 생략하고 싶은 경우에는 좀 더 전방부를 추천하였다. Cunha 등[8]은 유한요소분석에서 임플란트가 전방에 위치 할수록 임플란트에 가해지는 응력은 증가하지만, 지대치 에 가해지는 응력과 전체적인 응력은 감소하므로 전치부 치아만 잔존 시 지대치에 가까운 제 2소구치 부위에 임플 란트를 식립할 것을 추천하였다. 반면, $\mathrm{Kim}$ 등[9]은 하악 후방연장 국소의치에서 제 2 대구치에 위치한 임플란트 주 변골에 더 낮은 응력집중도를 보였고, 제 1 대구치에 위치 한 임플란트는 임플란트의 변위와 전방 지대치에 가해지 는 응력이 더 적어, 무치악부 지지가 주 목적이라면 후방 부에 식립할 것을, 건전하지 못한 지대치를 보조할 때에는 좀 더 전방 지대치에 가깝게 식립할 것을 추천하였다.

Bortolini 등[10]은 견치 또는 제 1 소구치가 골질과 골량 이 적당해 주요 식립 위치로 언급하였다. Brudvik [11]은 대구치 부위에 식립 시 Kennedy class I 또는 II에서 III로 변화되어 biomechanical configuration이 향상되며, 견치 부 위는 최후방 지대치가 측절치일 때 지지와 유지를 제공하 며 전방부 클라스프 생략으로 전방 지대치에 좋은 심미적, 치주적 예후를 제공한다고 하였다. Binon[12]은 식립 위치 가 고정성 보철 수복처럼 중요하지는 않다고 하였으며, 식 립 위치보다는 하중의 방향이 임플란트의 장축을 따라 가 해지는 것이 더욱 중요하다고 하였다.

국소의치 설계 시 이상적인 의치의 지지와 유지를 얻기 위해서는 지대 자연치아와 식립될 임플란트가 넓은 네 개 의 꼭지점을 가진 사다리꼴이 되도록 임플란트를 식립해 외팔보 효과를 방지해야 한다[13]. 특히 대칭적인 지지가 결여된 편측성으로 치아가 잔존하는 경우에 국소의치 설 계 시 반드시 이점을 고려하여 좌우 및 전후방적으로 전 략적인 위치에 임플란트를 식립해야 한다.

임플란트 보조 국소의치의 유지장치로 사용되는 Locator ${ }^{\mathbb{R}}$ 유지장치는 자가배열, 이중유지, 유지력이 상실되지 않으 면서 약간의 회전을 허용하는 특성이 있고 수직적으로 필 요한 공간이 작다는 장점이 있다. 그러나 다른 유지장치들 과 같이 반복적인 의치의 착탈과 기능 시 하중에 의한 유 지장치의 마모로 인한 유지력 상실과 나일론 부품의 교체, 지대주 함요부의 치태 축적에 의한 피개의치의 완전한 장 착의 방해, 지대주의 풀림, 의치의 재이장, 인공치 또는 의 치의 파절 등이 Locator ${ }^{\circledR}$ 유지장치와 관련된 유지 관리 문 제로 보고되고 있다[14]. 따라서 환자에게 구강위생관리 교육과 함께 정기적인 내원 시 Locator $^{\circledR}$ 지대주의 풀림이 나 마모 여부를 검사하고 유지력 저하 시 나일론 부품을 교체하는 것이 필요하며 잔존치조제의 흡수에 따른 의치 상의 침하를 방지하기 위해 주기적인 의치상의 재이장을 실시해야 한다. 
본 증례는 상악은 전치부만 잔존하고 하악은 편측으로 소수 치아가 잔존하는 환자로 구치부 지지와 저작 기능의 회복이 필요하였으며, 하악은 외팔보 효과를 방지하고 추 가적인 유지와 지지를 얻기 위해 임플란트 식립이 추천되 는 상황이었다. 치주적으로 약한 전방 지대치를 보호하기 위해 하악 우측 중절치에 근접하면서도 수평적 가용골이 풍부한 \#32와 \#33 사이를 전방 임플란트 식립 위치로 선 택하였으며, 대합치 및 반대측 자연치아와 대칭적 위치면 서 수평적 가용골이 풍부한 \#34와 \#35 사이를 후방 임플 란트 식립 위치로 선택하였다. 따라서 잔존 자연 지대치와 추가되는 임플란트가 비교적 넓은 사다리꼴 분포를 이루 도록 하였다. 향후 잔존 치아와 임플란트 및 국소의치의 지속적인 평가 및 유지관리가 요구된다.

\section{결 론}

중심선에 대해 편측으로 소수의 치아가 잔존하는 환자 의 가철성 국소의치 수복에서는 중심선을 기준으로 반대 측의 전략적 위치에 임플란트를 식립하여 임플란트 보조 국소의치를 제작하면 의치의 유지와 지지 그리고 잔존 지 대치의 예후를 향상시킬 수 있다. 이를 위해서는 체계적인 진단 과정이 필요하고 다양한 요인을 고려하여 적절한 위 치에 임플란트를 식립하고 응력 분산을 하는 것이 중요하 며 주기적인 유지 관리가 필수적이다.

\section{Conflict of Interest}

The authors declare that they have no competing interests.

\section{ORCID}

$\begin{array}{ll}\text { Hyo-Gyoung Yi } & 0000-0001-9402-7869 \\ \text { Kwang-Yeob Song } & 0000-0003-4283-1278 \\ \text { Seung-Geun Ahn } & 0000-0002-9105-931 X \\ \text { Ju-Mi Park } & 0000-0003-1910-1525 \\ \text { Jae-Min Seo } & 0000-0001-5095-4046\end{array}$

\section{References}

1. Budtz-Jorgensen E. Restoration of the partially edentulous mouth-a comparison of overdentures, removable partial dentures, fixed partial dentures and implant treatment. J Dent 1996;24:237-244. doi: 10.1016/0300-5712 (95)00075-5.

2. Lee JH, Kim DG, Park CJ, Cho LR. A literature review on implant assisted removable partial denture. J Dent Rehabil Appl Sci 2012;28:179-190.

3. Ohkubo C, Kurihara D, Shimpo H, Suzuki Y, Kokubo Y, Hosoi T. Effect of implant support on distal extension removable partial dentures: in vitro assessment. J Oral Rehabil 2007;34:52-56. doi: 10.1111/j.1365-2842.2006. 01641.x.

4. Lee BR, Kim JH. Rehabilitation of maxillary partial edentulous patients using implant assisted removable partial denture. J Korean Acad Prosthodont 2014;52:128135. doi: 10.4047/jkap.2014.52.2.128.

5. Carr AB, Brown DT. McCracken's removable partial prosthodontics. 12th ed. St. Louis: Mosby; 2011. p. 66, 340-341.

6. Wismeijer D, Tawse-Smith A, Payne AG. Multicentre prospective evaluation of implant-assisted mandibular bilateral distal extension removable partial dentures: patient satisfaction. Clinical Oral Implants Res 2013;24:20-27. doi: 10.1111/j.1600-0501.2011.02367.x.

7. Grossmann Y, Nissan J, Levin L. Clinical effectiveness of implant-supported removable partial dentures: A review. of the literature and retrospective case evaluation. J Oral Maxillofac Surg 2009;67:1941-1946. doi: 10.1016/j.joms. 2009.04.081.

8. Cunha LD, Pellizzer EP, Verri FR, Pereira JA. Evaluation of the influence of location of osseointegrated implants associated with mandibular removable partial dentures. Implant Dent 2008; 17:278-287. doi: 10.1097/ID.0b013e31818363b2.

9. Kim JH, Cho JH, Lee $\mathrm{CH}$. Influence of the length and location of implants on distal extension removable partial dentures: finite element analysis. J Dent Rehabil Appl Sci 2015;31:186-194. doi: 10.14368/jdras.2015.31.3.186.

10. Bortolini S, Natali A, Franchi M, Coggiola A, Consolo U. Implant-retained removable partial dentures: an 8year retrospective study. J Prosthodont 2011;20:168-172. doi: 10.1111/j.1532-849X.2011.00700.x.

11. Brudvik JS. Advanced removable partial dentures. Chicago: Quintessence; 1999. p. 153-159.

12. Binon P. The role of screws in implant systems. Int $\mathbf{J}$ Oral Maxillofac Implants 1994;9:48-63.

13. Zitzmann NU, Rohner U, Weiger R, Krastl G. When to choose which retention element to use for removable dental prostheses. Int J Prosthodont 2009;22:161-167.

14. Cha MS, Kim DG, Park CJ, Cho LR. A literature review on locator attachment for implant overdenture. J Dent Rehabil Appl Sci 2013;29:127-140. doi: 10.14368/jdras. 2013.29.2.127. 